Document downloaded from:

http://hdl.handle.net/10251/85522

This paper must be cited as:

Azagra Caro, JM. (2014). Determinants of national patent ownership by public research organisations and universities. Journal of Technology Transfer. 39(6):898-914. doi:10.1007/s10961-013-9322-y.

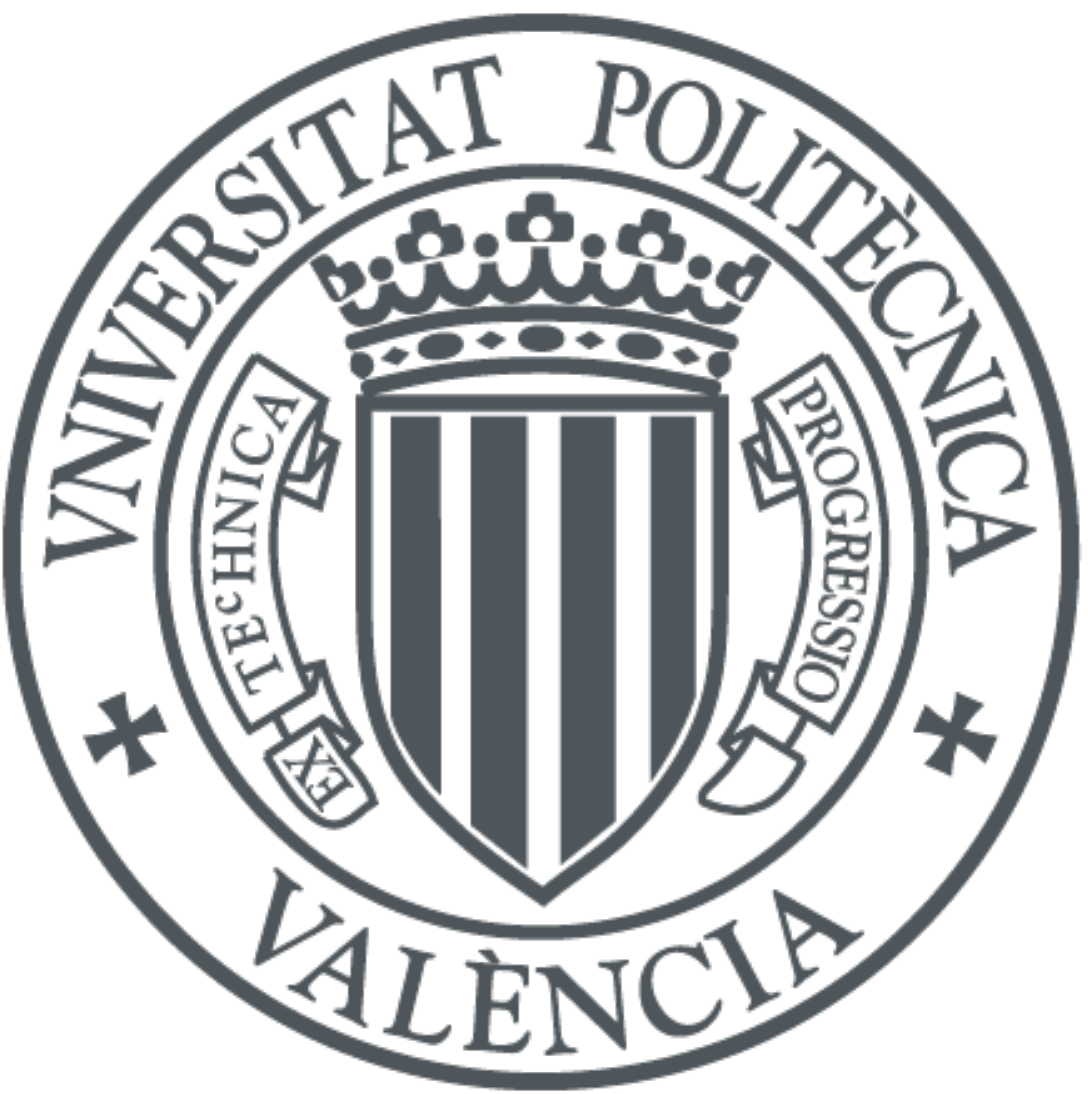

The final publication is available at

http://doi.org/10.1007/s10961-013-9322-y

Copyright Springer Verlag (Germany)

Additional Information 


\title{
Determinants of national patent ownership by public research
}

\section{organisations and universities}

\author{
Joaquín M. Azagra-Caro * \\ INGENIO (CSIC-UPV), Universitat Politècnica de València, Camino de Vera s/n, E-46022 Valencia, Spain; \\ European Commission, Joint Research Centre (JRC), Institute for Prospective Technological Studies (IPTS), \\ Edificio Expo, c/Inca Garcilaso 3, 41092 Sevilla, Spain
}

\begin{abstract}
This paper focuses on the question of whether the national production functions of patents owned by universities and public research organisations (PROs) differ. We use Eurostat patent and R\&D data broken down by institutional sector for the European Union 27 and other countries in years 1982-2007, and we estimate dynamic panel models. The impact of R\&D expenditure on patent ownership is higher for PROs than for universities. University patent ownership activity is dependent on business funding, while PRO patent ownership is not. We recommend a reversal of the current decline of PRO R\&D expenditure and discuss whether PROs perform better at macroeconomic level vis a vis universities.
\end{abstract}

Keywords: academic patenting; technology transfer; scientific production

JEL Codes: O31 - Innovation and Invention: Processes and Incentives; O34 - Intellectual Property Rights

\section{Introduction}

University patents form part of the markets for science and technology. They are a measure of research production that describes the conduct of universities and a technology transfer

"Corresponding author. Tel.: +34963877007, ext: 78439; fax: +34963877991.

E-mail address: jazagra@ingenio.upv.es

The views expressed in this article are those of the authors and do not necessarily reflect those of the European Commission. Neither the European Commission nor any person acting on behalf of the Commission is responsible for the use that might be made of the information.

Present address: INGENIO (CSIC-UPV), Ciudad Politécnica de la Innovación Edif. 8E 4 , Camino de Vera $\mathrm{s} / \mathrm{n}, 46022$ Valencia. 
mechanism responsive to changes in public policy (Goel and Rich 2005). The trend for universities to apply for and own patents has been increasing in the EU for some decades. There are several reasons for the rise in the number of university-owned patents: changes in knowledge production increasing the capacity of university researchers to produce patentable inventions and scientific publications (Meyer 2006; Baldini 2006b; Azagra et al. 2007a; Breschi et al. 2008; Baldini 2009) ${ }^{1}$, policy support based on the belief that the EU is less productive than the US (Dosi et al. 2006), access to industry knowledge, practical experience and the possibilities for its application (Arvanitis et al. 2008), and changes in societal demand and funding conditions. These reasons have been the motivation for regulatory changes in some countries to allow universities to own patents (Baldini 2006a; Baldini et al. 2006) and in universities to share royalties with academic inventors and departments (Baldini 2010) or to accommodate IPR sharing with partners (Okamuro and Nishimura 2013). Patents are one of the few benefits in common of establishing partnerships for university and industry (Ankra et al. 2013), although academics mainly use patents for commercialisation and prefer other channels of interaction for research purposes (Gaughan and Corley 2010; D’Este and Perkmann 2011).

It is unfortunate that PROs have not attracted as much research attention as universities. Government laboratories are an important part of many national innovation systems (Nelson and Rosenberg, 1993). In most countries, the top patenting public institutions are the large PROs, for example, the National Center for Scientific Research (CNRS) in France, the National Research Council (CNR) in Italy and the Spanish National Research Council (CSIC) in Spain (Cesaroni and Piccaluga 2005), rather than universities. PROs, like universities, need to justify their public funding, and analysis of universities on their own provides incomplete information for systems where university and PRO activity is intertwined (Bach and Llerena

\footnotetext{
${ }^{1}$ Although there is no consensus on the extent (Ponomariov, 2007; Yang and Chang, 2010), and the positive relation is clearer in North America than in other geographical areas (Wong and Singh, 2009).
} 
2007). PROs are also under pressure to increase their visibility through patent ownership, but may approach this problem in different ways.

The objective of this paper is to compare the production of patents owned by universities and PROs using country-years as the unit of observation. The two main research questions are: Is the impact of $\mathrm{R} \& \mathrm{D}$ expenditure on patent ownership higher for PROs than for universities? Is the impact of the share of business funding of $R \& D$ on patent ownership higher for universities than for PROs?

Section 2 provides a review of the literature and Section 3 discusses the data and methodology used in this paper, Section 4 presents the results, and Section 5 concludes.

\section{Literature review and research hypotheses}

\subsection{Differences between the determinants of university and PRO patent ownership}

In many of the microeconomic production functions estimated using universities as the unit of observation (Coupé 2003; Azagra et al. 2003; 2006a, b; 2007a; Baldini et al. 2006; Carayol 2007; Acosta et al. 2008; Wong and Singh 2009; Baldini 2009), one of the theoretical determinants of university-owned patents is university R\&D expenditures and/or other measures for university research size, such as R\&D staff. The impact of R\&D on patents tends to be positive and significant, with elasticities lower than 1.

For instance, Coupé (2003), focusing on the elasticity of university R\&D in US, finds evidence of decreasing returns to scale. Microeconomic studies on the European context, using departments, institutes and labs within universities, point to decreasing returns to $R \& D$ expenditure in the production of university patents (Azagra et al. 2003; Azagra et al. 2006a). At the level of universities, Baldini et al. (2006) show some evidence of no impact on their proxy for size (budget transfer from central government). 
Mesoeconomic analyses for the Spanish regions suggest that returns to R\&D expenditure are increasing for universities, based perhaps on spillover effects due to the higher level of aggregation (Azagra et al. 2006b; 2007a). However, the Spanish case may be peculiar due to the small average size of the country's universities. For the EU-15, still at regional level, returns to R\&D expenditure appear to be constant in the period 1998 to 2002 (Acosta et al. 2008). To what extent these results apply at country level, for the EU-27, and over a longer time span is unknown; given the slightly more abundant microeconomic evidence, we expect low returns to $R \& D$ expenditure when using countries as the unit of observation. Indirect support to this assumption is the finding that regional university $R \& D$ expenditure does not affect the number of forward references to European university-owned patents (Acosta et al. 2012).

Several scholars have described patent ownership by PROs (e.g. Cesaroni and Piccaluga 2005; Potì and Reale 2005; Bach and Llerena 2007; Moutinho et al. 2007). Some include patenting as a predictor of other phenomena, like publication output (Buenstorf 2009), academic entrepreneurship (Krabel and Mueller 2009) and technology transfer (Grimpe and Fier 2010). However, to our knowledge, the only application of the patent production function in the context of PRO-owned patents is the work by Azagra et al. (2007b), which provides microeconomic evidence for the case of CSIC, the largest Spanish PRO. They find a large elasticity of the size variable used - research staff, closely related to R\&D expenditure, but also - and in contrast to universities - the presence of increasing returns to R\&D. They suggest that university departments, laboratories and whole universities grow in terms of teaching function, while PROs grow based on R\&D demand to reach critical mass.

The above reasoning justifies the expected impact of $R \& D$ on patents to be low for universities and high for PROs, so we hypothesise that: 
Hypothesis 1. The impact of R\&D expenditure on patent ownership is higher for PROs than for universities.

Funding from industry, based on increased contracting out of R\&D to universities and PROs, is an important component of university R\&D funding (Geuna et al. 2004). However, the impact of this funding is difficult to predict. Traditionally, firms are more likely to use IPR methods, and this may be influencing universities to do the same (Azagra et al. 2003). However, firms are more likely to own the results of the research they fund, which may explain why university-owned patents are more responsive to public funding and universityinvented patents more responsive to private funding (Azagra et al. 2006a). If both types of patents are considered, the positive effect of private funding predominates, at the laboratory (Azagra et al. 2006a) and the individual level (Carayol 2007).

The impact of business funding on patent ownership among PROs has received little attention. While many PROs have a long-standing tradition of patenting, the involvement of European universities in patenting is mostly relatively recent. Traditionally, universities mostly engage in project-based research. Among PROs, some perform more project-based research (e.g. CNRS, CSIC, Max Planck Society), and others are contract research institutions (Fraunhofer Society, VTT). Hence, PROs are more acquainted with patenting and patent ownership regardless of the level of funding from private sources. Azagra et al.'s (2007b) measure of business funding related to CSIC research is not significant. We can hypothesise that:

Hypothesis 2. The impact of the share of business funding of R\&D expenditure on patent ownership is higher for universities than for PROs. 


\subsection{Other determinants of university and PRO patent ownership at macroeconomic level}

The firm's patent/R\&D ratio is a priori a good indicator that captures national peculiarities related to IPRs or, as Meyer et al. (2005) argue, the determinants of the wider (national, cultural) drivers of academic inventive activity. It includes the differences in legal systems and cultures related to patent application and helps to explain whether patent ownership by universities is related to local framework conditions.

We also need to introduce R\&D expenditures by PROs when explaining patent production of universities and vice versa. The two realms of public research (PROs and universities) interact together. Universities are very likely to benefit from PRO's R\&D expenditure, and the other way round. A model of patent ownership has to accept this possibility, especially in the light of national differences.

Finally, it seems convenient to control for national level involvement in university and PRO-invented patents. Lissoni et al. (2008) pose the question of why do European universities not retain the IPRs over their scientists' inventions? The implication is that university-owned and university-invented patents represent different alternatives for technology transfer: licensing and signalling (implicit in university-owned patents) or research for/with industry (university-invented patents). National legal and institutional frameworks play a major role. Some include more incentives for individual researchers to gain academic prestige or personal income, independent of the regulatory framework allowing university staff to own patents. If these alternatives are complements, that is, if academics are active inventors in patents owned by their universities (PROs) and patents owned by other institutions, then university (PRO) patent ownership will not reduce technology transfer. This applies to universities and PROs, since both engage into collaborative agreements with companies that may result into the company filing a patent with equal probability (NúñezSánchez et al. 2012). 


\subsection{Dynamic effects/National institutional histories}

Regarding the regulatory conditions specific to IPRs at universities and PROs, recall the academic debate starting in the US following the Bayh-Dole Act, which allows universities to apply for patents based on their R\&D. Other countries with different institutional frameworks show higher or lower numbers of university or PRO patents. In the EU the following general statements apply (again, the case of universities is better documented than that of PROs).

- The ownership regime of PROs varies over time. Some countries privatised (notably the UK) some of their PROs in the late 1990s (PREST 2002), which may be promoting higher patent ownership in these institutions.

- The strength of knowledge transfer offices varies across countries, with a longer tradition in the UK and Spain (Proton 2007), which may be increasing the number of university and PRO-owned patents.

- In France, there is a strong link between PROs and universities, so co-patenting is frequent. The IPRs belong to the applying institution, and the 1999 Innovation Law increased the incentives for universities to apply for patents.

- Some high-income countries have low levels of university or PRO patent ownership because the legislative framework does not allow it. This may be the explanation for low levels in Denmark, Germany and Austria, which moved from systems based on professor's privilege (professors had the first right to apply for the patent, followed by the university) to a more US-like system (the university has the priority) only in 2000, 2001 and 2002, respectively (Baldini 2006). In other Scandinavian countries, such as Finland (Meyer et al. 2005) or Sweden (Lissoni et al. 2008; Nilsson et al. 2010), inventors still have ownership rights. 
- In the exceptional case of Italy, inventor privilege was superior to university privilege only between 2001 and 2004 (Potì and Reale 2005; Baldini et al. 2006). The changed pattern may be the explanation for the growing number of university-owned patents.

- In countries where regulation is unclear, the number of patents generally is lower. In Portugal, for example, institutions retain the ownership, but there are no specific regulations regarding royalty shares, duty of disclosure or the period allowed for the decision to patent. In Greece patent ownership is subject to negotiation (Cesaroni and Piccaluga 2005).

- Analyses of university patents in the new EU member states are few. Most of these countries are former communist economies and although IPR technical requirements were similar, the individual incentives to patent were much smaller (Marinova 2001). These states have been classified as a block of "countries where IPR ownership was assigned to the State and which switched to institutional ownership after the early 1990s' (Geuna and Rossi 2011).

It is beyond the scope of our model to find specific variables that capture the nature of each one of these phenomena. However, in order to take them into account, we will propose dynamic models where the patenting history of academic institutions forms part of the explanation of current patent ownership. This way, any measured influences of our target variables (R\&D expenditure and share of business funding) will be conditioned on this history, i.e. any impact of $R \& D$ expenditure and share of business funding will represent the effect of new information.

\section{Data}

We use panel data on number of university and PRO-owned patents, and university and PRO R\&D expenditure in millions of Purchasing Power Standards (PPS) deflated at 1995 
prices, from Eurostat's online database, which is regularly updated. The unit of observation is one country in one year.

Data on patents refer to applications to the European Patent Office (EPO). Years of the patents are those of the priority date, which are more meaningful than application or grant date, from a technological or economic point of view, because it is the closest to the date of invention (OECD 2001). Although data go back to 1977, the period of observation starts in 1982 to match available information for the R\&D variable. The year 2007 is the last available with information on patents. Our sample period is 26 years. The initial sample countries are the $27 \mathrm{EU}$ member states (although we will widen the sample in a later robustness check). The distinction between institutional sectors (universities and PROs) is based on Eurostat's project on Data Production Methods for Harmonised Patent Statistics (Van Looy et al. 2006). Geuna and Rossi (2011) use similar data to describe changes in university patenting in Europe. In the estimations, we will refer to two samples, the university and the PRO samples, but the unit of observation will be the same -the country-year.

A limitation of using EPO patents is the possible home advantage effect which may underestimate the number of US patents. However, the effect has been studied only for multinational firms and not academic institutions. In the context of firms, patents have several limitations such as representing a mix of discoveries with widely differing economic value. However, Patel and Pavitt (1995) argue that we can expect similar and large variations in the value of R\&D across all countries. In the specific case of universities or PROs and EPO patents, there are other advantages. First, for these institutions patents are a proxy not of innovation but of ownership of scientific results. Second, there are fewer differences because patents tend to be concentrated in science-based sectors (Pavitt 1998) and universities or PROs only take out patents through the EPO for their (potentially) most valuable inventions (Azagra et al. 2006b). 
Regarding R\&D expenditure, our data refer to the extensively used measure compiled by Eurostat from national surveys, following the OECD Frascati Manual. In relation to number of patents, there is a lag of one period in order to reduce endogeneity. ${ }^{2}$

A limitation of matching patent and $\mathrm{R} \& \mathrm{D}$ databases is the sectoral distribution of hospitals. While patent statistics classify all hospitals into a single category, R\&D statistics classify them the categories of business enterprise, government, higher education and private nonprofit. Therefore, relating PRO patents to PRO R\&D expenditure means we cannot include patents applied for by public, non-university hospitals, but we will be counting their R\&D expenditure. The same applies to university patents and R\&D from university hospitals. To compare universities and PROs, this is not a problem if the same share of hospital patents is subtracted from university and PRO patents. If the number of hospital patents is randomly assigned across countries, this will cancel out unobservable differences. In any case, the number of hospital patents is around 6 per cent of academic patents, so the difference is not likely to be dramatic.

The panel starts with 728 observations, but after matching patent and R\&D data, 347 are non-missing for the university sample and 357 for the PRO sample. The number of observations further decreases to 247 for universities and 258 for PROs because of the need to use one or two periods less, according to the econometric approach that follows.

\footnotetext{
${ }^{2}$ This is not to imply that it takes 1 year between R\&D spending and applying for a patent, since the possibilities are enormous. The assumption is that 1 -year-lagged R\&D expenditure is a good enough predictor of what will happen to patents in the next period, because 1-year-old R\&D expenditure already incorporates information from older R\&D expenditure. In addition, most studies dealing with the R\&D-patent relationship use a 1-year lagged value of $R \& D$ expenditure, probably because of its quite contemporaneous relation with patents (Hall et al. 1986).
} 


\section{Econometric approach}

\subsection{Model and variables}

We consider academic (university or PRO) patent ownership a dynamic process. Hence, in addition to those variables suggested in the literature review, we include the lagged dependent variable in the right hand side of the model to be estimated:

$\mathrm{Ln}$ \# of academic - owned patents $_{\mathrm{i}, \mathrm{t}}=\sum_{j=1}^{m} \beta_{j} \mathrm{Ln} \#$ of academic - owned patents $_{\mathrm{i}, \mathrm{t}-\mathrm{j}}+$

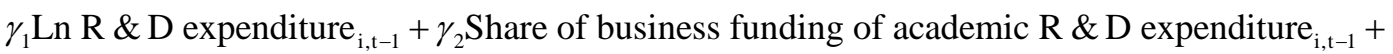

$\gamma_{3}$ Share of university R \& D expenditure $_{\mathrm{i}, t-1}+\gamma_{4} \mathrm{Ln}$ firm patent / R \& D ratio $\mathrm{i}_{\mathrm{i}, \mathrm{t}-1}+$

$\sum_{j=1}^{2} \delta_{j}$ Share of business - owned patents $\mathrm{i}_{\mathrm{i}, \mathrm{t}-\mathrm{j}}+$ Trend $_{\mathrm{t}}+\alpha_{i}+\varepsilon_{i, t}$

“Academic" may mean either universities or PROs, depending on the sample. The subscript i stands for country, $t$ for year.

In order to eliminate the individual effect, the model is converted into first differences. The resulting equation has dependent variable:

$$
\begin{aligned}
& \Delta \mathrm{Ln} \# \text { of academic }- \text { owned patents }_{\mathrm{i}, \mathrm{t}}=\mathrm{Ln} \# \text { of academic }- \text { owned patents }_{\mathrm{i}, \mathrm{t}}- \\
& \Delta \mathrm{Ln} \# \text { of academic }- \text { owned patents }_{\mathrm{i}, \mathrm{t}-1}
\end{aligned}
$$

We use lags of the dependent variable as instruments and obtain Generalised Method of Moments (GMM) estimators. Specifically, we use the Arellano-Bond method (Arellano and Bond 1991). ${ }^{3}$ The number of lags, $\mathrm{j}$, is initially one, but if specification tests suggest the presence of autocorrelation, we add more lags until we correct it (two lags maximum have been needed). The number of instruments is not limited unless the Sargan tests suggests the

\footnotetext{
${ }^{3}$ We have also run standard panel regression techniques, with time dummies instead of a trend, and models with autocorrelation, all with similar results.
} 
presence of overidentifying restrictions, and in this case, we reduce the number of instruments.

Table 1 lists the definitions and Table 2 the descriptive statistics for the patent and R\&D variables and the other determinants of university and PRO patents.

\{Table 1 around here

\{Table 2 around here

The variable labelled in the tables as "share of business-owned patents" deserves additional explanation. It is a proxy for academic staff as inventors of patents not owned by universities or PROs -commonly known as academic-invented patents - calculated as:

$$
\text { Share of business }- \text { owned patents }=\frac{\text { Business }- \text { owned patents }}{\text { Business }- \text { owned patents }+ \text { Academic }- \text { owned patents }}
$$

The denominator represents the maximum number of patents in which academic researchers may appear as inventors; the numerator expresses the maximum number of business-owned patents on which academic researchers may appear as inventors. Thus, the more business-owned patents in the economy in relation to the total number of patents held by both business enterprises and academic institutions, the more likely academic staff will be named on patents applied for by firms.

This ratio will be equal to 1 if there are no academic-owned patents (academic staff more likely to be named as inventors on business patents) and will tend to zero as the number of academic-owned patents increases (academic staff less likely to be inventors on business patents). That is, the variable expresses the potential proportion of business patents with academic inventors: higher values indicate higher potential proportions of business patents 
with academic inventors. A negative sign of the regression coefficient indicates some substitution between owned and invented patents. ${ }^{4}$

Since the denominator includes academic-owned patents, we treat the variable as endogenous and use two lags as GMM-type instruments for differenced equation.

The choice of the dynamic panel model techniques is driven for the theoretical justification of considering the history of the dependent variable and for the way we have measured academic patenting (through the "share of business-owned patents" proxy), but not for the presence of unit root in single variables. According to the Fisher-type augmented DickeyFuller tests for panel data (available upon request), the series are mostly stationary with a drift term, except for the logarithm of university R\&D expenditure, which becomes stationary when a time trend is included. Most series on PRO patents and R\&D are stationary even without a drift term or a time trend, suggesting that time variation is not important for the estimations. We report models where the constant acts as a drift term, and with a time trend.

\subsection{Estimation of university and PRO-owned patent production functions}

Table 3 presents econometric results. Column 1 includes the estimation of equation 1 in first differences for the EU27 country-years' university sample. The specification tests detect neither autocorrelation nor overidentifying restrictions, so the specification of the model is correct. Column 2 includes the estimation for the EU27 country-years' PRO sample. The Sargan test does not detect overidentification but the autocorrelation tests detect serial correlation of second order. Hence, we add one lag of the dependent variable to the specification and re-estimate equation 1 in Column 3. The tests now indicate that the

\footnotetext{
${ }^{4}$ Of course, this ratio is not a perfect measure, but there are no data on number academic-invented patents for the time and geographic scope we analyse. The closest attempt to generating these data is Crespi et al. (2010) for 6 European countries. Their measure of university-invented patents correlates perfectly with ours and produces the same national ranking, so it gives some validity to our proxy. However, the correlation, although lower, is negative and still high in the case of PROs, and the national ranking is substantially different, which makes us cautious about using our proxy for the conclusions.
} 
specification of the model is appropriate. Hence, we compare Columns 1 and 3 to verify our hypotheses (notice, however, that using Column 2 instead of 3 for comparison would have led to the same verification, which gives some robustness to the results).

The lagged dependent variables are significant for PRO-owned patents but not for university-owned ones. This is interesting because, as mentioned in the introduction and in section 2.3, there has been more emphasis on IPR regulatory frameworks related to universities rather than to PROs. The former result suggests, however, that these frameworks are more determining for IPR at PROs than at universities, at least when the unit of analysis is the country, as in this paper. A possible explanation is the higher heterogeneity of PROs across countries compared to that of universities (also tackled in the introduction and section 2.3.) This is not the focus of this paper, though, but verifying Hypotheses 1 and 2 is -which we do next.

\{Table 4 around here $\}$

The relation between university-owned patents and university $R \& D$ expenditure is not significant: the money universities spend on $R \& D$ does not have any effect on the number of patents they apply for. The same is not true for the relation between PRO-owned patents and PRO R\&D expenditure. The relation between PRO-owned patents and PRO R\&D expenditure is positive and significant: the more money PROs spend on R\&D, the more patents they apply for. This provides evidence that the coefficient of R\&D is significantly larger for PROs than for universities. Hence, the evidence supports Hypothesis 1.

A Wald test indicates that the coefficient of PRO R\&D expenditures is significantly lower than 1. A possible interpretation is that, other things equal, small countries are more efficient than large countries for PRO patent ownership as a ratio of PRO R\&D expenditure.

The relation between university-owned patents and the share of business funding of university $R \& D$ expenditure is positive and significant: the larger the proportion of industry 
funding of universities, the higher the number of university patents. For PROs, the lack of significance of the funding structure is a difference with universities: a higher proportion of private funding is not conducive to patent ownership. Hence, the evidence favours that the impact of the share of business funding is larger for universities, which confirms Hypothesis 2.

\subsection{Results about control variables}

The share of university $R \& D$ expenditure has no significant effect on patent ownership neither for universities nor for PROs. Hence, the structure of the public research expenditure does not seem decisive.

The firm patent/R\&D ratio has a positive, significant impact on patent ownership for both universities and PROs, suggesting that the latter are influenced by the same patenting rules as the rest of the economy.

The first-year lags of the share of business-owned patents and PRO-invented patents have a negative, significant effect on the number of university-owned and PRO-owned patents, respectively. This result gives some support to the idea that the involvement of universities and PROs in patent ownership is excluding their involvement in invention. The second-year lag is not significant.

The trend is significant for university- but not for PRO-owned patents. This is consistent with the fact that the unit root tests detected trend stationarity in university R\&D and drift stationarity in all the PRO-related series. We also replaced the trend with time dummies and results were similar. Specifically, time dummies were significant from 1996 for the university sample and not significant in the PRO sample. 


\subsection{Robustness checks}

The results also hold in models estimated without robust standard errors (which are necessary to compute the Sargan test) or in models not treating the share of business-owned patents as an endogenous variable. We may still wonder whether the number of observations is too small.

In order to alleviate this problem, in Columns 4 to 6 we extend the analysis to all countries included in Eurostat's patents and R\&D statistics (not only EU). Hence, the number of observations increases. The specification tests suggest that the model for universities in Column 4 is correct. In Column 5, for PROs, the Sargan test indicates that there are overidentifying restrictions. We reduce the number of instruments and present the reestimated model in Column 6, where the Sargan test indicates that this problem is solved. Comparison between Columns 4 and 6 leads to the same verification as before: acceptance of Hypotheses 1 and 2 (comparison between Column 4 and 5 would have led to the same result). The sign and significance of the control variables are also the same as in Columns 1 and 3.

We have also explored nonlinearities in R\&D and share of business funding by introducing their square terms as independent variables. $R \& D$ squared is highly collinear with the original R\&D variable (even after centering both), so the results are unreliable. Share of business funding squared presents no collinearity problems. It is not significant and the rest of results hold, so we did not consider it worth showing the results (available upon request).

\section{Limitations}

This research is only a first step, which additional analysis would refine. Productivity analysis in this area increasingly relies on fine-grained micro-data to tackle the problems associated with the aggregated data of the type the paper uses, e.g. matching academic 
inventor names to patent databases (Dietz and Bozeman 2005; Lissoni et al. 2008; Czarnitzki et al. 2012) or survey evidence. However, such studies find it hard to relate numbers of patents to monetary data, e.g. $R \& D$ expenditures, because $R \& D$ data are not attributable to micro units like individual researchers. Hence, our approach provides another interesting angle to the subject.

A disadvantage of our study that we cannot break down patents according to technology classes because Eurostat does not publish that data at the institutional level. Nevertheless, although it would allow for performing an additional robustness check, it is not clear how it would change our hypotheses. Hence, from the theoretical point of view, this paper still poses interesting questions and the evidence shown is just a first approach.

The way PROs are presented in this paper is far from a unified set of organizations, as acknowledged in the literature review. In general, the PRO grouping is more heterogeneous than universities while also being less standardized in terms of research agendas, funding schemes, etc. The role that public R\&D plays for different sections of PROs is an element of the Frascati manual and its current revision: in some countries the PROs in question are defined as private sector. The Eurostat definition of PRO patents (which uses name-matching) does not take such details into consideration when identifying PRO patents. This can amplify the mismatch between funding and patents. We have tried to partially control for this by using dynamic panel models and performing robustness checks, but of course, common standards of data production about institutional allocation of $R \& D$ and patent data would be better.

Similarly, there are differences among universities. Some research universities are more active in patenting compared to other teaching-oriented institutions. Controlling for the type of universities in the country would allow for a more accurate comparison with PROs. However, the relevant data are not available for the time and country coverage of this study. 
We hope that on aggregate differences of this kind will cancel out and, as in the case of PROs, that our techniques have mitigated possible remaining problems.

\section{Conclusions}

The analysis in this paper tries to be a preliminary step to approach the production of patents in universities and in PROs on the average of different countries, in light of relative $R \& D$ expenditures. The panel approach to gauge the relative magnitudes of expenditures and patent rates provides a rough-and-ready measure to handle the relative importance of patenting (by country and over time) of these institutional sectors, in light of the concurrent development of patenting in the business enterprise sector and other control factors.

The prevailing policy recommendations concerning university and PRO patent ownership are mainly managerial: designing simple and harmonised IPRs allowing for knowledge transfer and cooperation between public research and industry (EC 2007b); pooling resources between several knowledge transfer offices, implementing model contracts which make publishing and patenting compatible (EC 2007a), etc. According to our research, it would be useful to extend this view to an economic perspective that considers the role of R\&D in the process. By doing so, policy targets would find it justified: (i) inverting the current decline of PRO R\&D expenditure, because it is detrimental to the desired objective of increasing PRO owned- patents ${ }^{5}$; (ii) using the characteristics of PRO patent ownership as a benchmark for universities, because they present two advantages:

First, PROs have own R\&D linked to patent production, which may introduce criteria for efficiency, i.e. an elasticity of R\&D lower than 1 at national level prevails in the case of PROowned patents, indicating that smaller countries are more efficient than larger ones. No such

\footnotetext{
${ }^{5}$ According to Eurostat data, for PROs, and as opposed to universities, R\&D is decreasing in real terms (the growth rate between 1981 and 2006 was $-24 \%$ ).
} 
relation can be established in the case of universities. This difference may be due to the universities' teaching mission, which does not apply to PROs. R\&D at universities is spread across scientific outcomes, such as patenting and teaching, whereas at PROs it is focused exclusively on patenting. Increasing the synergies between university scientific products and teaching would make universities more comparable to PROs in terms of patent-ownership.

Second, PROs produce patents with independence of business funding, in contrast with universities, which need such funding. It is yet to be seen whether the former is really better, but at least it reduces the fear of excessive industrial influence on public science. Certainly, PROs have different roles in the countries within the EU, so more fine-grained research should find which types of PROs are leading this result before making this conclusion applicable to all countries.

\section{Acknowledgements}

This research started within the framework of ERAWATCH, a joint initiative of the European Commission's Directorate General for Research and the Joint Research CentreInstitute for Prospective Technological Studies (IPTS). Without the continuous support of René van Bavel and Xabier Goenaga, in the IPTS Knowledge for Growth (KfG) Unit, it would not have been possible to carry it on. Numerous conversations with Pablo D'Este, Sean Kask, Jordi Molas-Gallart, Dimitrios Pontikakis, Francesco Rentocchini and María Rochina were helpful for content and methodological issues. Colleagues from the KfG Unit provided enriching comments during seminar presentations. Attendants at the $3^{\text {rd }}$ Annual Conference of the EPIP Association, the $2^{\text {nd }}$ COMMUNIA Conference and the 2012 European Seminar EuroLIO offered valuable ideas, with a special mention to my discussants Isabel M. BodasFreitas and Benjamin Coriat. Martin Meyer gave a helpful hand about institutional concerns. 
Finally, Jeff Furman and Francesco Lissoni revised former versions of the paper and made extremely profitable comments.

\section{References}

Acosta, D., Coronado D., León, M.D., Martínez, M., 2008. Production of university technological knowledge in European regions: evidence from patent data. Regional Studies, 43 (9): 1167-1181.

Acosta, D., Coronado D., Martínez, M., 2012. Spatial differences in the quality of university patenting: Do regions matter? Research Policy, 41 (9): 692-703.

Ankrah, S.N., Burgess, T.F., Grimshaw, P., Shaw, N.E., 2013. Asking both university and industry actors about their engagement in knowledge transfer: What single-group studies of motives omit. Technovation 33: 50-65.

Arellano, M., Bond, S., 1991. Some tests of specification for panel data: Monte Carlo evidence and an application to employment equations. Review of Economic Studies 58: 277-297.

Arvanitis, S., Kubli, U., Woerter, M., 2008. University-industry knowledge and technology transfer in Switzerland: What university scientists think about co-operation with private enterprises. Research Policy 37: $1865-1883$

Azagra Caro, J.M., Fernández de Lucio, I. Gutiérrez Gracia, A. 2003. University patents: output and input indicators... of what? Research Evaluation, 12 (1): 5-16.

Azagra-Caro, J.M., Archontakis, F., Yegros-Yegros, A., 2007a. In which regions do universities patent and publish more? Scientometrics 70 (2): 251-266

Azagra-Caro, J.M., Carayol, N., Llerena, P., 2006a. Patent Production at a European Research University: Exploratory Evidence at the Laboratory Level. Journal of Technology Transfer, 31 (3): 257-268.

Azagra-Caro, J.M., Plaza-Gómez, L., Romero-de-Pablos, A., 2007b. The origin of public research organisation patents: an economic approach. Research Evaluation 16 (4): 271-282

Azagra-Caro, J.M., Yegros-Yegros, A., Archontakis, F., 2006b. What do university patent routes indicate at regional level? Scientometrics, 66 (1): 219-230.

Bach, L., Llerena, P., 2007. Indicators of higher-education institutes and public-research organizations technology transfer activities: insights from France. Science and Public Policy 34 (10): 709-721.

Baldini, N., 2006a. The Act on inventions at public research institutions: Danish universities' patenting activity. Scientometrics 69 (2): 387-407. 
Baldini, N., 2006b. University patenting and licensing activity: a review of the literature. Research Evaluation 15 (3), 197-207.

Baldini, N., 2009. Implementing Bayh-Dole-Like Laws: Faculty Problems and Their Impact on University Patenting Activity. Research Policy 38 (8): 1217-1224.

Baldini, N., 2010. Do royalties really foster university patenting activity? An answer from Italy. Technovation 30: 109-116.

Baldini, N., Grimaldi, R., Sobrero, M., 2006. Institutional changes and the commercialization of academic knowledge: A study of Italian universities' patenting activities between 1965 and 2002. Research Policy 35 : 518-532.

Breschi, S., Lissoni, F., Montobbio, F. (2008). University patenting and scientific productivity: a quantitative study of Italian academic inventors. European Management Review 5: 91-109.

Buenstorf, G., 2009. Is commercialization good or bad for science? Individual-level evidence from the Max Planck Society. Research Policy 38: 281-292.

Carayol, N., 2007. Academic incentives, research organization and patenting at a large French university. Economics of Innovation and New Technology, 16 (2): 119-138.

Cesaroni, F., Piccaluga, A., 2005. Universities and Intellectual Property Rights in Southern European Countries. Technology Analysis \& Strategic Management 17 (4): 497-518.

Coupé, T., 2003. Science is Golden: Academic R\&D and University Patents. Journal of Technology Transfer, 28: 31-46.

Crespi, G.A., Geuna, A., Nomaler, Ö., Verspagen, B., 2010. University IPRs and knowledge transfer: is university ownership more efficient? Economics of Innovation and New Technology 19(7): 627-648.

Czarnitzki, D., Hussinger, K., Schneider, C., 2012. The nexus between science and industry: evidence from faculty inventions. Journal of Technology Transfer 37 (5): 755-776.

D’Este, P., Perkmann, M., 2011. Why do academics engage with industry? The entrepreneurial university and individual motivations. Journal of Technology Transfer 36 (3): 316-339.

Dietz, J.S., Bozeman, B., 2005. Academic careers, patents, and productivity: industry experience as scientific and technical human capital. Research Policy 34 (3): 349-367.

Dosi, G., Llerena, P., Labini, M.S., 2006. Science-Technology-Industry Links and the 'European Paradox': Some Notes on the Dynamics of Scientific and Technological Research in Europe. In: Lorenz, E.H., 
Lundvall, B.-Å. (eds.), How Europe's Economies Learn: Coordinating competing models. Oxford: Oxford University Press.

EC, 2007a. Commission communication 'Improving knowledge transfer between research institutions and industry across Europe: embracing open innovation', $\operatorname{COM}(2007) 182$.

EC, 2007b. Commission Green Paper 'The European Research Area: New Perspectives', COM(2007) 161.

Gaughan, M. and Corley, E.A., 2010. Science faculty at US research universities: The impacts of university research center-affiliation and gender on industrial activities. Technovation 30: 215-222.

Geuna, A., Llerena, P., Matt, M., Savona, M., 2004. Collaboration between a research university and firms and other institutions. In: Cesaroni, F., Gambardella, A., García-Fontes, W. (eds.): R\&D, innovation, and competitiveness in the European chemical industry. Boston: Kluwer, ch. 6.

Geuna, A., Rossi, F., 2011. Changes to university IPR regulations in Europe and the impact on academic patenting. Research Policy 40: 1068-1076.

Grimpe, C., Fier, H., 2010. Informal university technology transfer: a comparison between the United States and Germany. Journal of Technology Transfer 35 (6): 637-650.

Hall, B. H., Griliches, Z., Hausman, J. A., 1986. Patents and R\&D: Is there a lag? International Economic Review 27 (2): 265-283.

Krabel, S., Mueller, P., 2009. What drives scientists to start their own company? An empirical investigation of Max Planck Society scientists. Research Policy 38: 947-956.

Lissoni, F., Llerena, P., McKelvey, M., Sanditov, B., 2008. Academic patenting in Europe: new evidence from the KEINS database. Research Evaluation 17 (2): 87-102.

Marinova, D., 2001. Eastern European patenting activities in the USA. Technovation 21: 571-584.

Meyer, M., 2006. Are patenting scientists the better scholars? An exploratory comparison of inventor-authors with their non-inventing peers in nano-science and technology. Research Policy 35 (2006) 1646-1662.

Meyer, M., Du Pleiss, M., Tukeva, T., Utecht, J.T., 2005. Inventive output of academic research: a comparison of two science systems. Scientometrics 63 (1): 145-161.

Moutinho, P.S.F., Fontes, M., Godinho, M.M., 2007. Do individual factors matter? A survey of scientists' patenting in Portuguese public research organizations. Scientometrics 70 (2): 355-377.

Nelson, R.R., Rosenberg, N., 1993. Technical Innovation and national Systems. In: Nelson, R.R. (ed.), National Innovation Systems. New York-Oxford: Oxford University Press. Chapter 1. 
Nilsson, A.S., Rickne, A., Bengtsson, L., 2010. Transfer of academic research: uncovering the grey zone. Journal of Technology Transfer 35 (6): 617-636.

Núñez-Sánchez, R., Barge-Gil, A., Modrego-Rico, A., 2012. Performance of knowledge interactions between public research centres and industrial firms in Spain: a project-level analysis. Journal of Technology Transfer 37: $330-354$.

OECD, 2001. Using Patent Counts for Cross-Country Comparisons of Technology Output. STI Review 27.

Okamuro, H., Nishimura, J., 2013. Impact of university intellectual property policy on the performance of university-industry research collaboration. Journal of Technology Transfer 38 (3): 273-301.

Patel, P., Pavitt, K., 1995. Patterns of technological activity: their measurement and interpretation. In: Stoneman, P. (ed.), Handbook of the Economics of Innovation and Technological Change, ch. 2. UK: Blackwell.

Pavitt, K., 1998. Do patents reflect the useful research output of universities? Research evaluation 7 (2): 105-11.

Ponomariov, B.L., 2007. Effects of university characteristics on scientists' interactions with the private sector: an exploratory assessment. Journal of Technology Transfer 33 (5): 485-503.

Potì, B., Reale, E., 2005. The patenting regime in the Italian public research system. What motivates public inventors to patent. Ceris-Cnr, Working Paper $N^{\circ} 10 / 2005$.

PREST, 2002. A Comparative Analysis of Public, Semi-Public and Recently Privatised Research Centres, mimeo: ftp://ftp.cordis.europa.eu/pub/indicators/docs/ind_report_prest1.pdf, last access: 20/02/2009.

Proton, 2007. The ProTon Europe 2005 Annual Survey report, mimeo: http://www.fpttpftt.gc.ca/eng/resources/articles/2007/06/ProTonEurope2005.html, last access: 20/02/2009.

Van Looy, B., du Plessis, M.,Magerman, T., 2006. Data Production Methods for Harmonized Patent Indicators: Assignee sector allocation. Eurostat Working Paper and Studies, Luxembourg.

Wong, P.K., Singh, A., 2009. University patenting activities and their link to the quantity and quality of scientific publications. Scientometrics, 83:271-294.

Yang, P.Y., Chang, Y.-C., 2010. Academic research commercialization and knowledge production and diffusion: the moderating effects of entrepreneurial commitment. Scientometrics, 83:403-421.

\section{Unlinked reference}

Furman, J.L., Porter, M.E., Stern, S., 2002. The determinants of national innovative capacity. Research Policy 31: 899-933. 


\section{Tables}

Table 1

Variables and definitions

\begin{tabular}{|c|c|}
\hline Variable & Definition \\
\hline \multicolumn{2}{|l|}{ University sample } \\
\hline \# of academic-owned patents & $\begin{array}{l}\text { Number of patent applications filed by } \\
\text { universities at the European Patent Office (EPO) }\end{array}$ \\
\hline R\&D expenditure & $\begin{array}{l}\text { Higher education R\&D expenditure in millions of } \\
\text { Purchasing Power Standards (PPS) deflated at } \\
1995 \text { prices } 1\end{array}$ \\
\hline $\begin{array}{l}\text { Share of business funding of } \\
\text { academic R\&D }\end{array}$ & $\begin{array}{l}\text { Ratio of business funding of higher education } \\
\text { R\&D expenditure over total higher education } \\
\text { R\&D expenditure }\end{array}$ \\
\hline Share of business-owned patents & $\begin{array}{l}\text { Number of business patents over the sum of } \\
\text { business plus university patents }\end{array}$ \\
\hline \multicolumn{2}{|l|}{ PRO sample } \\
\hline \# of academic-owned patents & $\begin{array}{l}\text { Number of patent applications filed by } \\
\text { government at the European Patent Office (EPO) }\end{array}$ \\
\hline $\mathrm{R} \& \mathrm{D}$ expenditure & $\begin{array}{l}\text { Government R\&D expenditure in millions of PPS } \\
\text { deflated at } 1995 \text { prices }\end{array}$ \\
\hline $\begin{array}{l}\text { Share of business funding of } \\
\text { academic } R \& D\end{array}$ & $\begin{array}{l}\text { Ratio of business funding of government R\&D } \\
\text { expenditure over total government R\&D } \\
\text { expenditure }\end{array}$ \\
\hline Share of business-owned patents & $\begin{array}{l}\text { Number of business patents over the sum of } \\
\text { business plus government patents }\end{array}$ \\
\hline \multicolumn{2}{|l|}{ Both samples } \\
\hline $\begin{array}{l}\text { Share of university R\&D } \\
\text { expenditure }\end{array}$ & $\begin{array}{l}\text { Ratio of higher education } R \& D \text { expenditure over } \\
\text { the sum of higher education } R \& D \text { expenditure } \\
\text { plus government } R \& D \text { expenditure }\end{array}$ \\
\hline Firm patent/R\&D ratio & $\begin{array}{l}\text { Ratio of the number of patents owned by business } \\
\text { firms over the business firm's expenditure on } \\
\text { R\&D }\end{array}$ \\
\hline Trend & Priority year \\
\hline
\end{tabular}

Data source: Eurostat's online database, which is regularly updated. We downloaded data in September 2012 (http://epp.eurostat.ec.europa.eu/portal/page/portal/science_technology_innovation/data/database)

\footnotetext{
${ }^{1}$ Instead of expenditure on R\&D, we tried R\&D personnel. The two variables were highly correlated, so we do not include them in the same estimation. The fit was always better for expenditure than for personnel (as in Azagra et al. 2007a). We used other human capital variables, such as number of researchers and ratio of R\&D expenditure to R\&D personnel or researchers, but this did not provide any additional information. They also presents the disadvantage that the data for US are very incomplete in Eurostat.

${ }^{2}$ We tried estimations adding share of government funding of R\&D, but they were not significant.
} 
Table 2

Descriptive statistics of the variables

\begin{tabular}{lllll}
\hline Variable & Mean & Std. dev. & Minimum & Maximum \\
\hline University sample (N=347) & & & & \\
$\quad$ \# of academic-owned patents & 93.01 & 256.54 & 0.06 & 1465.76 \\
$\quad$ R\&D expenditure & $3,145.16$ & $5,928.45$ & 10.00 & 35100.00 \\
$\quad$ Share of business funding of academic & & & 0.00 & 0.50 \\
$\quad$ & 0.06 & 0.07 & & \\
$\quad$ R\&D & 0.27 & 0.18 & 0.00 & 1.23 \\
$\quad$ Firm patent/R\&D ratio & 0.45 & 0.17 & 0.11 & 0.94 \\
$\quad$ Share of university R\&D expenditure & 0.96 & 0.06 & 0.33 & 1.00 \\
$\quad$ Share of business-owned patents & & & & \\
PRO sample (N=357) & 42.77 & 71.96 & 0.03 & 373.37 \\
$\quad$ \# of academic-owned patents & $3,120.56$ & $6,420.26$ & 10.00 & 29730.00 \\
$\quad$ R\&D expenditure & & & 0.00 & 0.27 \\
$\quad$ Share of business funding of academic & & & & \\
$\quad$ R\&D & 0.07 & 0.06 & 0.00 & 0.77 \\
$\quad$ Firm patent/R\&D ratio & 0.55 & 0.16 & 0.00 & 0.89 \\
$\quad$ Share of university R\&D expenditure & 0.98 & 0.03 & 0.63 & 1.00 \\
$\quad$ Share of business-owned patents & & & & \\
\hline
\end{tabular}


Table 3

Arellano-Bond dynamic panel-data estimation of the determinants of academic (university or PRO)-owned patents

\begin{tabular}{|c|c|c|c|c|c|c|}
\hline & $\begin{array}{l}1 \\
\text { Ln \# of university- } \\
\text { owned patents }\end{array}$ & $\begin{array}{l}2 \\
\text { Ln \# of PRO-owned } \\
\text { patents (one-lagged } \\
\text { dep. variable) }\end{array}$ & $\begin{array}{l}3 \\
\text { Ln \# of PRO-owned } \\
\text { patents (two-lagged } \\
\text { dep. variables) }\end{array}$ & $\begin{array}{l}4 \\
\text { Ln \# of university- } \\
\text { owned patents (not } \\
\text { only EU) }\end{array}$ & $\begin{array}{l}5 \\
\text { Ln \# of PRO- } \\
\text { owned patents } \\
\text { (not only EU) }\end{array}$ & $\begin{array}{l}6 \\
\text { Ln \# of PRO-owned } \\
\text { patents (not only } \\
\text { EU, limited number } \\
\text { of instruments) }\end{array}$ \\
\hline Ln lagged \# of academic-owned patents (lag 1) & $\begin{array}{l}0.11 \\
(0.09)\end{array}$ & $\begin{array}{l}0.32 * * * \\
(0.09)\end{array}$ & $\begin{array}{l}0.21 * * \\
(0.10)\end{array}$ & $\begin{array}{l}0.17 \\
(0.10)\end{array}$ & $\begin{array}{l}0.33 * * * \\
(0.10)\end{array}$ & $\begin{array}{l}0.06 \\
(0.18)\end{array}$ \\
\hline Ln lagged \# of academic-owned patents (lag 2) & & & $\begin{array}{l}0.29 * * * \\
(0.07)\end{array}$ & & & \\
\hline Ln R\&D expenditure & $\begin{array}{l}-0.01 \\
(0.23)\end{array}$ & $\begin{array}{l}0.90 * * * \\
(0.26)\end{array}$ & $\begin{array}{l}0.62 * * * \\
(0.19)\end{array}$ & $\begin{array}{l}-0.20 \\
(0.25)\end{array}$ & $\begin{array}{l}0.51 * * \\
(0.25)\end{array}$ & $\begin{array}{l}0.61 * * * \\
(0.23)\end{array}$ \\
\hline Share of business funding of academic R\&D & $\begin{array}{l}2.89 * * * \\
(0.98)\end{array}$ & $\begin{array}{l}1.50 \\
(0.78)\end{array}$ & $\begin{array}{l}-0.54 \\
(0.56)\end{array}$ & $\begin{array}{l}2.23 * * \\
(0.90)\end{array}$ & $\begin{array}{l}-0.57 \\
(0.92)\end{array}$ & $\begin{array}{l}-0.43 \\
(1.68)\end{array}$ \\
\hline Ln firm patent/R\&D ratio & $\begin{array}{l}0.90 \text { *** } \\
(0.08)\end{array}$ & $\begin{array}{l}0.61 * * * \\
(0.18)\end{array}$ & $\begin{array}{l}0.55 * * * \\
(0.16)\end{array}$ & $\begin{array}{l}0.84 * * * \\
(0.08)\end{array}$ & $\begin{array}{l}0.57 * * * \\
(0.13)\end{array}$ & $\begin{array}{l}1.11 * * * \\
(0.23)\end{array}$ \\
\hline Share of university R\&D expenditure & $\begin{array}{l}0.09 \\
(0.76)\end{array}$ & $\begin{array}{l}2.02 * * \\
(0.87)\end{array}$ & $\begin{array}{l}1.07 \\
(0.66)\end{array}$ & $\begin{array}{l}-0.43 \\
(0.72)\end{array}$ & $\begin{array}{l}-0.06 \\
(0.99)\end{array}$ & $\begin{array}{l}1.13 \\
(1.46)\end{array}$ \\
\hline Share of business-owned patents (lag 1) & $\begin{array}{l}-16.05^{* * * *} \\
(1.95)\end{array}$ & $\begin{array}{l}-17.07 * * * \\
(4.81)\end{array}$ & $\begin{array}{l}-21.80 * * * \\
(6.72)\end{array}$ & $\begin{array}{l}-16.83 * * * \\
(1.91)\end{array}$ & $\begin{array}{l}-18.80 \text { *** } \\
(4.73)\end{array}$ & $\begin{array}{l}-24.00 * * * \\
(6.28)\end{array}$ \\
\hline Share of business-owned patents (lag 2) & $\begin{array}{l}2.97 \\
(1.69)\end{array}$ & $\begin{array}{l}10.64 * * \\
(4.36)\end{array}$ & $\begin{array}{l}4.71 \\
(2.54)\end{array}$ & $\begin{array}{l}3.81 * * \\
(1.57)\end{array}$ & $\begin{array}{l}11.01 * * \\
(4.62)\end{array}$ & $\begin{array}{l}7.41 \\
(6.41)\end{array}$ \\
\hline Trend & $\begin{array}{l}0.08 * * * \\
(0.02)\end{array}$ & $\begin{array}{l}-0.02 \\
(0.01)\end{array}$ & $\begin{array}{l}-0.01 \\
(0.01)\end{array}$ & $\begin{array}{l}0.08 * * * \\
(0.01)\end{array}$ & $\begin{array}{l}0.01 \\
(0.01)\end{array}$ & $\begin{array}{l}-0.00 \\
(0.02)\end{array}$ \\
\hline Constant & $\begin{array}{l}-135.00 * * * \\
(32.19)\end{array}$ & $\begin{array}{l}46.61 \\
(27.41)\end{array}$ & $\begin{array}{l}35.03 \\
(20.79)\end{array}$ & $\begin{array}{l}-145.47 * * * \\
(29.04)\end{array}$ & $\begin{array}{l}-10.94 \\
(25.92)\end{array}$ & $\begin{array}{l}19.38 \\
(42.14)\end{array}$ \\
\hline Observations & 223 & 234 & 219 & 306 & 321 & 321 \\
\hline Groups & 21 & 19 & 17 & 27 & 26 & 26 \\
\hline$\chi^{2}$ & 1,222 & 172 & 942 & 794 & 122 & 68 \\
\hline $\operatorname{Prob}\left(\chi^{2}\right)$ & 0.00 & 0.00 & 0.00 & 0.00 & 0.00 & 0.00 \\
\hline Sargan test & 209 & 221 & 221 & 300 & $332 * *$ & 44 \\
\hline Autocorrelation tests & Not significant & Significant & Not significant & Not significant & Not significant & Not significant \\
\hline
\end{tabular}

*** Significant at 1\%.* Significant at 5\%. Robust standard errors in brackets. Sargan test calculated for model without robust standard errors. Share of business-owned patents is treated as an endogenous variable. 